\title{
Spatial Trends in the Texture, Moisture Content, and pH of a Virginia Coastal Plain Soil
}

\author{
S. Zacharias, C. D. Heatwole, J. B. Campbell
}

\begin{abstract}
Soil texture, moisture content, and pH data from an agricultural field area of $48 \times 32 \mathrm{~m}$ in a Suffolk sandy loam soil in the Virginia Coastal Plain was examined for spatial trends. Trend surface analysis of sand, silt, and clay content data $(n=35)$ found that $68 \%, 74 \%$, and $31 \%$ of the total variability in sand, silt, and clay content, respectively, was explained by second-order trend surfaces. Soil moisture content and $\mathrm{pH}$ also exhibited spatial trends, which resulted in statistically significant differences between subsurface moisture content and pH in two $18 \times 27 \mathrm{~m}$ subplots within the study area. Both moisture content and $\mathrm{pH}$ trends had some similarity to the trend for clay content. The spatial trends in these soil properties, however, did not translate directly into spatial trends in depth to center of bromide mass, indicating the influence of other factors in the variability of chemical distribution in the soil. Keywords. Spatial variability, Trend surface analysis, Bromide transport.
\end{abstract}

$\mathrm{T}$ he physical and chemical properties of natural soils have significant spatial variability. Differences exist not only between similar soil series but also between properties measured within a given soil type (Beckett and Webster, 1971; Nielsen et al., 1973; Russo and Bresler, 1981). Reviewing a number of studies of soil properties in the literature, Beckett and Webster (1971) found that up to 50\% of the total variability of a property found within a field occurred within a square meter of surface area. Recent trench studies (Wierenga et al., 1991; Russo and Bouton, 1992) have also demonstrated that large spatial variations in soil properties occur over small distances.

Natural variations in soil characteristics often occur as a result of soil formation processes; for example, variations in soil texture may result from weathering, erosion, or deposition processes (Rao and Wagenet, 1985). These natural variations can have a significant effect on other soil properties and on processes that take place in the soil. Bresler et al. (1984) identified soil texture and salinity as dominant factors responsible for the spatial variability of soil hydraulic conductivity in a 0.8 ha field of Hamra Red Mediterranean soil in Israel. On a 1.6 ha Oklahoma watershed, Williams et al. (1987) found that texture and available water in the topsoil and subsoil explained a large percentage of the variation in crop (grain sorghum) yield.

A field study conducted to characterize the fate and transport of atrazine, metolachlor, and bromide, in the top $1.5 \mathrm{~m}$ of two adjacent $18 \times 27 \mathrm{~m}$ plots in the Virginia

Article was submitted for publication in August 1996; reviewed and approved for publication by the Soil \& Water Div. of ASAE in July 1997.

The authors are Sebastian Zacharias, Research Associate, Conrad D. Heatwole, ASAE Member Engineer, Associate Professor, Dept. of Biological Systems Engineering, and James B. Campbell, Professor and Head, Dept. of Geography, Virginia Polytechnic Institute and State University, Blacksburg, Va. Corresponding author: Conrad D. Heatwole, Biological Systems Engineering, VPI\&SU, Blacksburg, VA 24061-0303; tel.: (540) 231-4858; fax: (540) 231-3199; e-mail: <heatwole@vt.edu>.
Coastal Plain over the corn growing season of 1990, showed large variations in herbicide and bromide concentrations in soil (Heatwole et al., 1992, 1997). Both plots were part of a field that was on a two-year no-till corn-bean-wheat rotation. One plot (TP) was plowed and disked before corn was planted and herbicides (atrazine and metolachlor) were applied, while the other plot (NT) remained no-till with a heavy soybean-wheat residue. Soil moisture content and soil $\mathrm{pH}$ measurements taken during the five month study showed a consistent difference in these properties in the subsurface layers that could not be attributed to differences in tillage on the plots. Soil $\mathrm{pH}$ was greater in the tilled plot as compared to the no-till plot, and mean soil moisture content in the 0.45 to $1.5 \mathrm{~m}$ depth on all except the first sampling date was higher in the tilled plot.

The objectives of this study were: (1) to determine if some of the variability in soil texture, moisture content, and $\mathrm{pH}$ at this study site could be explained by regional trends in the variables; and (2) to determine if there is a relationship between spatial variations in soil properties and spatial variations in bromide movement at the study site.

\section{MATERIALS AND METHODS \\ BACKGROUND DATA}

The study site was located within the Nomini Creek watershed in Westmoreland County, Virginia, on a Suffolk sandy loam (coarse-loamy, siliceous, thermic Typic Hapludult) soil, with a $2 \%$ slope towards north (fig. 1). Heatwole et al. $(1992,1997)$ used surface runoff monitoring and soil core sampling to characterize the fate and transport of atrazine, metolachlor, and bromide, in two adjacent $18 \times$ $27 \mathrm{~m}$ plots over the corn growing season of 1990. Atrazine, metolachlor, and bromide were applied on 25 April 1990 (day 115). A rainfall simulator was used to apply $37 \mathrm{~mm}$ of rainfall to the plots in $1 \mathrm{~h}, 40 \mathrm{~h}$ following pesticide application. Surface runoff quantity and quality measurements from the no-till and tilled plot were made over the five month period, from 25 April (day 115) to 29 September (day 272). Soil core samples were collected up to 


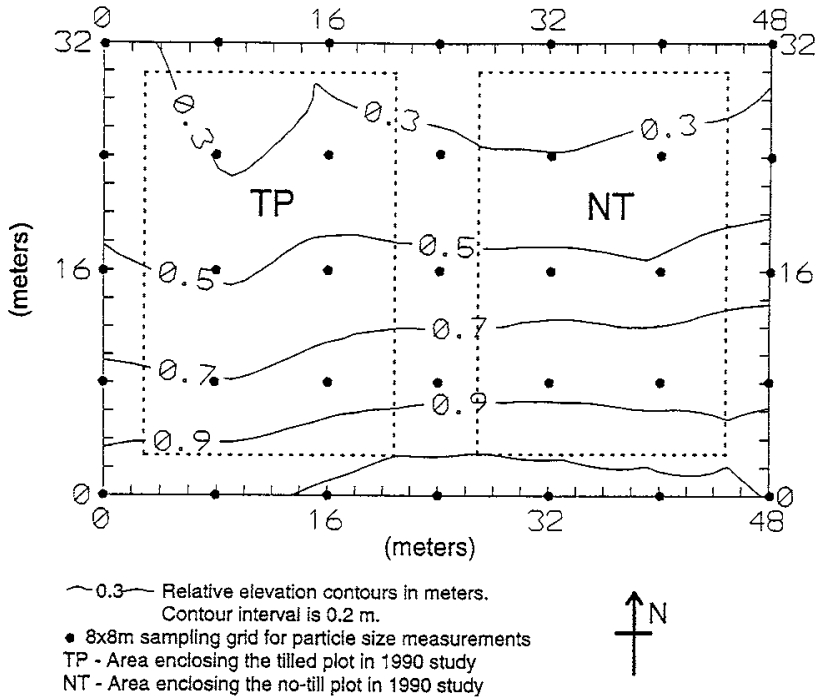

Figure 1-Study area, showing the sampling grid for the particle size measurements and the location of the 1990 field study plots.

$1.5 \mathrm{~m}$ depth at 20 random locations in the plot, six times following chemical application. The six sampling dates were days 118, 128, 145, 167, 209, and 272. Soil cores were collected at intervals of 0 to $0.01,0.01$ to $0.15,0.15$ to 0.3 , 0.3 to $0.45,0.45$ to $0.6,0.6$ to $0.9,0.9$ to 1.2 , and 1.2 to 1.5 $\mathrm{m}$. On the last sampling date (day 272), the top $0.15 \mathrm{~m}$ was sampled as one layer. The soil core samples were analyzed for atrazine, metolachlor, and bromide concentrations, as well as for gravimetric moisture content, $\mathrm{pH}$, and organic matter content (in the top $0.3 \mathrm{~m}$ ). Daily rainfall for the 157day study period is shown in figure 2 . There was $365 \mathrm{~mm}$ of precipitation in the first 34 days of the study period.

\section{Soil Texture SAmPling}

Additional soil samples were collected in June 1994 on a $8 \times 8 \mathrm{~m}$ grid from an area of $48 \times 32 \mathrm{~m}$ encompassing the two plots, to determine soil textural variations at the site. The location of the sampling grid, in relation to the location of the two plots of the 1990 field study (Heatwole et al., 1992, 1997) is shown in figure 1. Soil cores were taken from the 35 grid points at $0.15 \mathrm{~m}$ increments to a depth of $0.9 \mathrm{~m}$ using a $0.07 \mathrm{~m}$ diameter, $0.15-\mathrm{m}$ long stainless steel tube sampler. Samples at the four corners of the grid were taken to a depth of $1.5 \mathrm{~m}$. The soil samples were analyzed for particle size using the pipette method (Gee and Bauder, 1986).

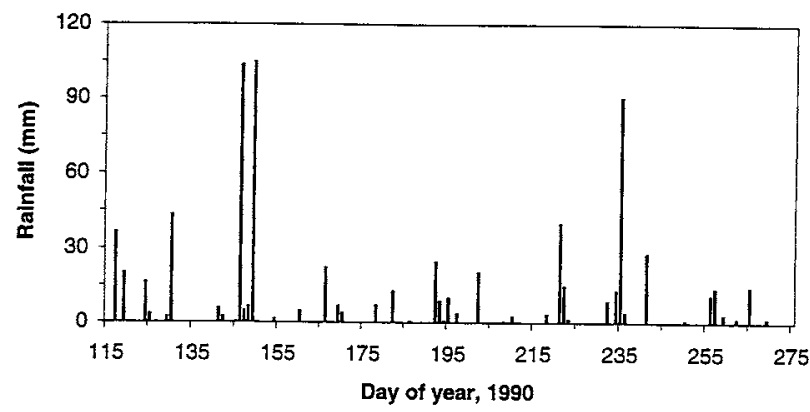

Figure 2-Daily rainfall at the study area for the duration of the 1990 field study (25 Apr. to 29 Sept.).

\section{Trend Surface Analysis}

Trend surface analysis is a statistical procedure used to partition the variance of a spatial random variable into two orthogonal components, one due to regional effects and the other due to local effects (Davis, 1986). The partitioning is usually achieved by estimating the variable using a polynomial equation in two perpendicular spatial axes. The coefficient of determination of the polynomial equation is an estimate of the proportion of variation explained by regional effects, and the rest of the variation is attributed to local effects and unexplained random variations. The polynomial equation is called a trend surface since it indicates any "regional" trends inherent in the data. Subtraction of this regional trend from the raw data gives a residual for each point. If there is no a priori reason for representing the local component by a particular distribution or if the local component is negligible, then it is combined with the error component, and together designated as the residual.

A trend surface model for the random response variable, $\mathrm{Z}$, is given by (Cooke et al., 1994):

$$
\begin{gathered}
Z_{K}=R_{K}+\varepsilon_{K} \\
R_{K}=\sum_{i=0}^{m} \sum_{j=0}^{i} \beta_{i+j} x^{m-j} y^{j}
\end{gathered}
$$

where $R_{K}$ is the regional component of the $\mathrm{K}$ th observation, and $\varepsilon_{\mathrm{K}}$ is the error component of the $\mathrm{K} t h$ observation, which may include a local component. Perpendicular spatial coordinates are $\mathrm{x}$ and $\mathrm{y}, \mathrm{m}$ is the order of the trend surface, and $\beta_{\mathrm{i}+\mathrm{j}}$ are coefficients. Trend surface analysis consists of determining the coefficients of the equations for the regional effects and testing inferences about them, and separating the local variations from the error component if they are of interest.

Trend surface analysis was performed using the routine of Cooke et al. (1994), which computes trend surfaces using least-squares, reweighted least-squares, least median of squares, and least trimmed squares procedures. The last three are robust procedures that are less susceptible to nonGaussian residuals or Gaussian residuals with outliers. In this study, results were based on the least-squares method as the data were approximately Gaussian and the leastsquares to reweighted least-squares efficiency ratio (Cooke et al., 1994) was low in most cases. For both the least squares and the reweighted least squares procedures, the routine performs an F-test to test the significance of each equation and a partial F-test (Davis, 1986) to test the significance of increase in fit due to a higher order model. While the coefficient of determination can be increased by increasing the order of the trend surface, the $p+1$ order model is selected only if the fit, as well as the increase in fit of the $p+1$ model over the $\mathrm{p}$ model, is found to be statistically significant at a prescribed confidence level $(\alpha$ $=0.05$ in this case). Based on the number of observations, we decided not to fit trend surfaces higher than third order for particle size and $\mathrm{pH}$ data and second order for moisture content and chemical data, although it was theoretically possible to fit higher order trends. 


\section{Depth Averaging of Soil Properties}

Particle size distribution and other soil properties were not uniform with depth, and these depth variations were removed before performing the trend surface analysis. The original data were arithmetic-averaged over depth to obtain a single depth-averaged value for each $\mathrm{x}, \mathrm{y}$ location. Bresler et al. (1984) identified depth-averaging of soil property to be the most appropriate method for identifying variations along the horizontal plane.

The depth-averaged value of a soil property was obtained by calculating a depth-weighted average of the variable for each sampling location, and is expressed mathematically as:

$$
\bar{V}_{i}\left(x_{i}, y_{i}\right)=\frac{\sum_{j=1}^{n} d_{j} V\left(x_{i}, y_{i}, z_{j}\right)}{\sum_{j=1}^{n} d_{j}}
$$

where $\bar{V}_{i}\left(x_{i}, y_{i}\right)$ is the depth-averaged value for the $i$ th location, $\mathrm{V}_{\mathrm{i}}\left(\mathrm{x}_{\mathrm{i}}, \mathrm{y}_{\mathrm{i}}, \mathrm{z}_{\mathrm{j}}\right)$ is the data at $\mathrm{i}$ th location and $\mathrm{j}$ th layer, and $d_{j}$ is the thickness of the $j$ th layer. For particle size data, $i=1,2, \ldots, 35$ and $j=1,2, \ldots, 6$, and for moisture content data, $\mathrm{i}=1,2, \ldots, 20$ in each plot, and $\mathrm{j}=$ $1,2, \ldots, 7$. Trend surfaces for $\mathrm{pH}$ were calculated by combining the depth-averaged data from the two plots (area of $42 \times 27 \mathrm{~m}$ ) under the assumption that tillage impacts on $\mathrm{pH}$ can be ignored. This resulted in a larger sample size (40 samples), and gave a better representation of the variability along the horizontal plane. Moisture content and depth to center of bromide mass from the two plots, however, were not combined for the trend surface analysis as the effect of tillage may be significant for those variables.

\section{Depth to Center of Mass}

The depth to center of mass, used as an indicator of bromide movement, was calculated from bromide concentrations in the various depth layers as:

$$
z_{c}=\frac{\sum_{i=1}^{n} C_{i} d_{i} z_{i}}{\sum_{i=1}^{n} C_{i} d_{i}}
$$

where $z_{c}$ is the depth to center of bromide mass from the soil surface, $\mathrm{C}_{\mathrm{i}}$ is bromide concentration in the $\mathrm{i}$ th layer, $\mathrm{d}_{\mathrm{i}}$ is the thickness of the $\mathrm{i}$ th layer, and $\mathrm{z}_{\mathrm{i}}$ is the depth to center of ith layer from the soil surface.

\section{RESULTS AND DisCUSSION SoIL TeXTURE}

Particle size distribution is summarized in table 1 . The increase in mean clay content to $0.45 \mathrm{~m}$ and a decrease in mean clay content below $0.45 \mathrm{~m}$ indicate the presence of an argillic horizon, which is typical of Hapludult soils. The depth of maximum clay content varied across the study area ranging from the 0.15 to $0.3 \mathrm{~m}$ layer to the 0.9 to

\begin{tabular}{|c|c|c|c|c|c|c|c|c|c|c|c|}
\hline \multirow{2}{*}{$\begin{array}{l}\text { Depth } \\
(\mathrm{m})\end{array}$} & \multirow[b]{2}{*}{$\mathrm{n}$} & \multicolumn{3}{|c|}{ Sand $(\%)$} & \multicolumn{3}{|c|}{ Silt (\%) } & \multicolumn{3}{|c|}{ Clay $(\%)$} & \multirow[b]{2}{*}{ Texture } \\
\hline & & Mean & Var & $\mathrm{D}$ & Mean & Var & D & Mean & Var & D $T$ & \\
\hline \multicolumn{12}{|c|}{ Raw data (layerwise) } \\
\hline $0-0.15$ & 35 & 71.6 & 5.8 & $0.120 \ddagger$ & 21.8 & 15.1 & $0.121 \neq$ & 6.6 & 25.0 & 0.099 & sl \\
\hline $0.15-0.3$ & 35 & 61.2 & 9.2 & 0.105 & 26.0 & 16.9 & $0.124 \ddagger$ & 12.8 & 35.8 & 0.116 & $6 \%$ \\
\hline $0.3-0.45$ & 35 & 58.1 & 15.6 & $0.114 \ddagger$ & 25.0 & 34.4 & $0.120 \%$ & 16.9 & 22.4 & 0.097 & 7 7 \\
\hline 0 & 35 & 65.3 & 22.8 & 0.154 & 19.0 & 56.8 & 0.191 & 15.7 & 34.4 & 0.128 & $8 \%$ \\
\hline $6-0$. & 35 & 72.7 & 21.7 & 0.164 & 14.6 & 69.7 & $0.137 \ddagger$ & 12.7 & 53.8 & 0.141 & 1 1末 \\
\hline $0.75-0.9$ & 35 & 79.1 & 18.3 & 0.176 & 10.4 & 86.8 & 0.175 & 10.5 & 57.4 & 0.166 & sl \\
\hline $0.9-1.05$ & 4 & 72.1 & 31.3 & & 4.7 & 94.1 & & 13.2 & 66.6 & & ${ }_{S 1}$ \\
\hline $1.05-1.2$ & 4 & 77.7 & 24.6 & & 12.1 & 79.6 & & 10.2 & 95.5 & & sl \\
\hline & 4 & 83.9 & 16.6 & & 10.0 & 74.9 & & 6.1 & 111.6 & & . \\
\hline $1.35-1.5$ & 4 & 85.8 & 9.7 & & 8.4 & 75.0 & & 5.8 & 42.8 & & ls \\
\hline
\end{tabular}

Table 1. Statistical characteristics* of particle size data collected from the study area

Raw data (combined layers)

$\begin{array}{lllllllllll}0-0.9 & 210 & 68.0 & 184.0 & 0.108 & 19.5 & 96.8 & 0.147 & 12.5 & 36.0 & 0.085\end{array}$

Depth-averaged data

$\begin{array}{lllllllllll}\text { Depth-averaged data } & & & & & & & & & & \end{array}$

Least squares residuals from parabolic trend surface of depth-averaged data $\begin{array}{lllllllllll}0-0.9 & 35 & 0.0 & 22.2 & 0.123 & 0.0 & 11.4 & 0.106 \% & 0.0 & 4.8 & 0.079\end{array}$

* Sample size (n), mean, variance (Var), Kolmogorov-Smirnov normality test statistic (D).

+ Soil textural class based on the mean values: $\mathrm{sl}$ - sandy loam, ls - loamy sand.

\# Null hypothesis (normal) is not rejected at the 0.05 level of significance.

Table 1. Statistical characteristics* of particle size data collected from the study area

\begin{tabular}{llll}
\hline Depth & Sand (\%) & Silt (\%) & Clay (\%)
\end{tabular}

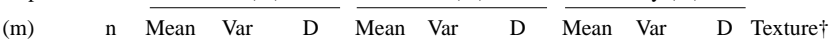

Raw data (layerwise)

$\begin{array}{llllllllllll}0-0.15 & 35 & 71.6 & 5.8 & 0.120 \div & 21.8 & 15.1 & 0.121 \neq & 6.6 & 25.0 & 0.099 \div & \text { sl }\end{array}$

$\begin{array}{lllllllllllll}0.15-0.3 & 35 & 61.2 & 9.2 & 0.105 \ddagger & 26.0 & 16.9 & 0.124 \ddagger & 12.8 & 35.8 & 0.116 \ddagger & \mathrm{sl}\end{array}$

$\begin{array}{llllllllllll}0.3-0.45 & 35 & 58.1 & 15.6 & 0.114 \ddagger & 25.0 & 34.4 & 0.120 \ddagger & 16.9 & 22.4 & 0.097 \ddagger & \text { sl }\end{array}$

$\begin{array}{llllllllllll}0.45-0.6 & 35 & 65.3 & 22.8 & 0.154 & 19.0 & 56.8 & 0.191 & 15.7 & 34.4 & 0.128 \ddagger & \text { sl }\end{array}$

$\begin{array}{llllllllllll}0.6-0.75 & 35 & 72.7 & 21.7 & 0.164 & 14.6 & 69.7 & 0.137 \$ 12.7 & 53.8 & 0.141 \% & \text { sl }\end{array}$

$\begin{array}{llllllllllll}0.75-0.9 & 35 & 79.1 & 18.3 & 0.176 & 10.4 & 86.8 & 0.175 & 10.5 & 57.4 & 0.166 & \mathrm{sl}\end{array}$

$\begin{array}{lrrrrrrrr}0.9-1.05 & 4 & 72.1 & 31.3 & 4.7 & 94.1 & 13.2 & 66.6 & \mathrm{sl}\end{array}$

$1.05 \mathrm{~m}$ layer, with the most occurrences in the 0.3 to $0.45 \mathrm{~m}$ layer (15 out of the 35 sampling points).

Trend surface analysis was performed on depthaveraged sand, silt, and clay content in the upper $0.9 \mathrm{~m}$ of the soil profile. The depth-averaged sand, silt, and clay content had greatly reduced variance (less than half) as compared to variance calculated from raw data combined for the six layers (table 1). The results from the trend surface analysis of depth-averaged particle size data are given in table 2; the order of the best fitting polynomial, determined from the tests of significance, are given along with the corresponding trend equation coefficients and coefficient of determination. Sixty-eight percent of the variability in sand was explained by the parabolic (second order) trend shown in figure 3a. Sand content was highest in the south west quadrant of the study area, decreasing to the north and to the east. The parabolic trend surface of clay content (fig. 3b) complements the sand content trend, with clay content increasing from the southwest quadrant to the north and to the east.

The residuals of these parabolic trend surfaces were random and had a zero mean (table 1). A semivariogram analysis of the particle size residuals indicated a pure nugget effect (Isaaks and Srivastava, 1989, pg. 305-307), which signifies a lack of spatial correlation.

The strong planar trends of sand, silt and clay content, along with depth variations in these properties, show that soil in the study area was highly variable. This level of heterogeneity, however, is not uncharacteristic of soils in the Coastal Plain region, soils formed by a combination of fluvial and marine action (W. J. Edmonds, 1996, personal communication). The planar variations can be best explained by the accretion of sediments as a result of 


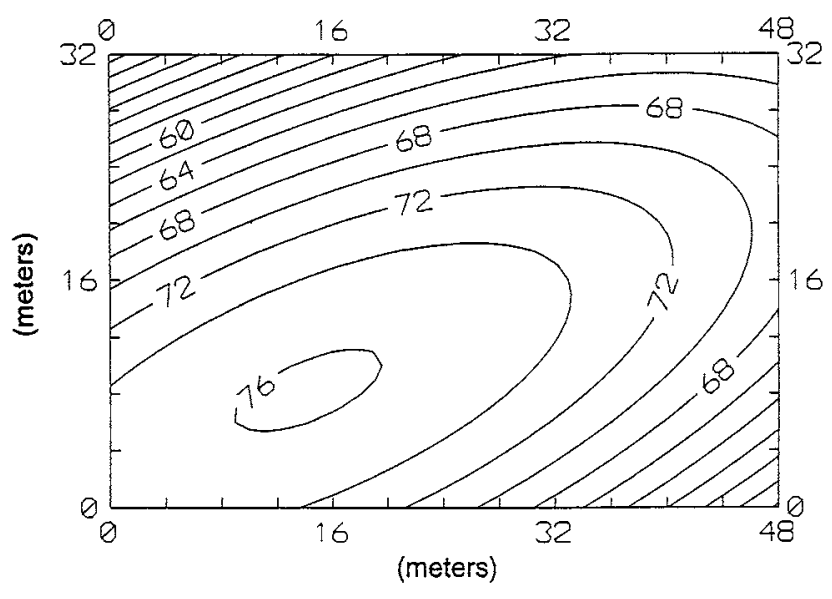

(a)

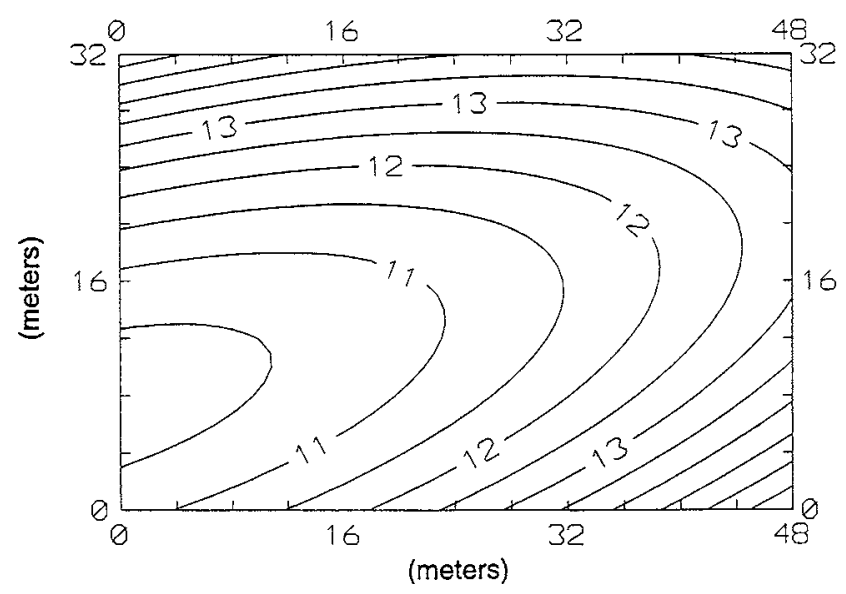

(b)

Figure 3-Trend surfaces of depth-averaged sand and clay content in the study area: (a) percent sand, (b) percent clay.

fluvial meandering streams and cross-stratification that commonly occurs as part of coastal clastic sedimentation (Matthews, 1974). While the depthwise increase in clay is likely due to eluviation of clay, the spatial variability in depthwise variations may be linked to the above-mentioned soil formation processes in the Coastal Plain.

\section{SoIL MoIsTure ConTent AND SoIl pH}

Soil moisture content and soil $\mathrm{pH}$ data from the 1990 field study showed distinct patterns in the deeper layers (table 3,4 ). Moisture content in the 0.45 to $1.2 \mathrm{~m}$ depths on all sampling dates except day 118 were consistently higher in the tilled plot, a response that could not be readily attributed to tillage effects. The t-test (Ott, 1993) showed many of the differences in the 0.45 to $1.2 \mathrm{~m}$ depth to be statistically significant at the $95 \%$ significance level (table 3). Higher soil moisture content in the top 0.3 or $0.45 \mathrm{~m}$ of the no-till plot may be due to higher infiltration rate found in no-till soils as compared to tilled soils. Also, higher infiltration rates and the possible compounding effect of macropores may have contributed to the higher moisture content throughout the no-till profile on day 118 as compared to the tilled profile.
Table 3. Summary statistics of gravimetric moisture content $(\mathrm{mm} / \mathrm{mm})$ in the two field plots by sampling date and depth

\begin{tabular}{|c|c|c|c|c|c|c|c|c|c|c|c|c|c|}
\hline \multirow{3}{*}{$\begin{array}{l}\text { Depth } \\
(\mathrm{m})\end{array}$} & \multirow[b]{3}{*}{ Plot* } & \multicolumn{12}{|c|}{ Day of Year, 1990} \\
\hline & & \multicolumn{2}{|c|}{118} & \multicolumn{2}{|c|}{128} & \multicolumn{2}{|l|}{145} & \multicolumn{2}{|c|}{167} & \multicolumn{2}{|c|}{209} & \multicolumn{2}{|l|}{272} \\
\hline & & Mean $\dagger$ & $\mathrm{CV} \ddagger$ & Mean & $\mathrm{CV}$ & Mean & $\mathrm{CV}$ & Mean & $\overline{\mathrm{CV}}$ & Mean & $\mathrm{CV}$ & Mean & $\mathrm{CV}$ \\
\hline $0-0.01$ & TP & $\mathrm{a}$ & 26 & $5 \mathrm{a}$ & 44 & a & 13 & a & 16 & $2 a$ & 44 & $\S$ & \\
\hline $0-0.01$ & NT & b & 22 & $13.3 \mathrm{~b}$ & 38 & $7.8 \mathrm{~b}$ & 24 & b & 36 & $6 \mathrm{~b}$ & 54 & $\S$ & \\
\hline $0.01-0.15$ & $5 \mathrm{TP}$ & $13.6 \mathrm{a}$ & 24 & $9.9 \mathrm{a}$ & 15 & $8.7 \mathrm{a}$ & 10 & $\mathrm{a}$ & 12 & $7 \mathrm{a}$ & 27 & $8.7 \mathrm{a}$ & 7 \\
\hline $0.01-0.15$ & $5 \mathrm{NT}$ & 1 & 15 & 11 & 15 & $9.4 \mathrm{~b}$ & 13 & $11.0 \mathrm{~b}$ & 15 & $\mathrm{~b}$ & 24 & $\mathrm{~b}$ & 44 \\
\hline $0.15-0.3$ & TP & $14.4 \mathrm{a}$ & 9 & a & 13 & 11.2 & 20 & 9.5 & 13 & $5.2 \mathrm{a}$ & 25 & $\mathrm{a}$ & 9 \\
\hline $0.15-0.3$ & NT & $16.8 \mathrm{~b}$ & 17 & $4 b$ & 10 & .8 & 18 & 13.7 & 75 & $7.6 \mathrm{~b}$ & 17 & $12.4 \mathrm{~b}$ & 24 \\
\hline $0.3-0.45$ & TP & $14.7 \mathrm{a}$ & 9 & 13.8 & 23 & 13.1 & 16 & 10.8 & 20 & $6.8 \mathrm{a}$ & 21 & 12.8 & 9 \\
\hline $0.3-0.45$ & NT & $18.8 \mathrm{~b}$ & 23 & & 18 & .0 & 12 & & 22 & $.1 \mathrm{~b}$ & 29 & & 30 \\
\hline $0.45-0.6$ & TP & 13.7 & 26 & 13.7 & 27 & $12.7 \mathrm{a}$ & 29 & 11.7 & 31 & 7.4 & 32 & 12.8 & 21 \\
\hline \multirow{2}{*}{$\begin{array}{l}0.45-0.6 \\
0.6-0.9\end{array}$} & NT & 15 & 29 & & 34 & $10.5 \mathrm{~b}$ & 24 & 9.6 & 31 & 6.8 & 36 & .5 & 11 \\
\hline & TP & 12 & 52 & 10 & 50 & $10.7 \mathrm{a}$ & 47 & $10.1 \mathrm{a}$ & 38 & $6.8 \mathrm{a}$ & 45 & $11.1 \mathrm{a}$ & 14 \\
\hline $0.6-0.9$ & NT & 15 & 41 & & 3 & $7.2 \mathrm{~b}$ & 27 & & 3 & $4.4 \mathrm{~b}$ & 40 & $\mathrm{~b}$ & 44 \\
\hline $0.9-1.2$ & TP & 9. & 38 & $9.4 \mathrm{a}$ & 48 & $8.7 \mathrm{a}$ & 42 & a & 35 & $5.4 \mathrm{a}$ & 55 & 5.9 & 56 \\
\hline $0.9-1.2$ & NT & 10.0 & 43 & $7.1 \mathrm{~b}$ & 18 & $5.8 \mathrm{~b}$ & 16 & $5.9 \mathrm{~b}$ & 15 & $3.6 \mathrm{~b}$ & 27 & 5.7 & 55 \\
\hline $1.2-1.5$ & TP & 9. & 30 & 8.6 & 24 & 7.8 & 16 & 7.8 & 24 & 4.9 & 40 & 5.2 & 37 \\
\hline $1.2-1.5$ & NT & & 50 & 7.5 & 21 & 7.5 & 50 & 6.8 & 17 & 4.8 & 35 & 6.4 & 41 \\
\hline \multirow{3}{*}{\multicolumn{14}{|c|}{$\begin{array}{l}* \text { TP - Tilled plot; NT - No-till plot. } \\
\dagger \text { Means }(\mathrm{n}=20) \text { for each date and depth, if followed by different letters, indicate } \\
\text { statistically significant differences in moisture content between the plots, by the two } \\
\text { sample t-test }(\alpha=0.05) \text {. }\end{array}$}} \\
\hline & & & & & & & & & & & & & \\
\hline & & & & & & & & & & & & & \\
\hline \multicolumn{10}{|c|}{$\begin{array}{l}\text { There were no surface }(0-0.01 \mathrm{~m}) \text { samples taken on day } 272 \text {; the first core was taken } \\
\text { at depth } 0-0.15 \mathrm{~m} \text {. }\end{array}$} & & & & \\
\hline
\end{tabular}

Table 3. Summary statistics of gravimetric moisture content $(\mathrm{mm} / \mathrm{mm})$ in the two field plots by sampling date and depth

\begin{tabular}{|c|c|c|c|c|c|c|c|c|c|c|c|c|c|}
\hline \multirow{3}{*}{$\begin{array}{l}\text { Depth } \\
\text { (m) }\end{array}$} & \multirow[b]{3}{*}{ Plot: } & \multicolumn{12}{|c|}{ Day of Year, 1990} \\
\hline & & \multicolumn{2}{|c|}{118} & \multicolumn{2}{|c|}{128} & \multicolumn{2}{|c|}{145} & \multicolumn{2}{|c|}{167} & \multicolumn{2}{|c|}{209} & \multicolumn{2}{|l|}{272} \\
\hline & & Mean $\dagger$ & $\mathrm{CV} \ddagger$ & Mean & $\mathrm{CV}$ & Mean & $\mathrm{CV}$ & Mean & $\mathrm{CV}$ & Mean & $\mathrm{CV}$ & Mean & $\mathrm{CV}$ \\
\hline 0.01 & TP & $13.4 \mathrm{a}$ & 26 & $5.5 \mathrm{a}$ & 44 & $4.2 \mathrm{a}$ & 13 & $12.2 \mathrm{a}$ & 16 & $2.2 \mathrm{a}$ & 44 & $\S$ & \\
\hline-0.01 & NT & $18.3 \mathrm{~b}$ & 22 & $13.3 \mathrm{~b}$ & 38 & $7.8 \mathrm{~b}$ & 24 & $16.9 \mathrm{~b}$ & 36 & $2.6 \mathrm{~b}$ & 54 & $\S$ & \\
\hline $.01-0.1$ & $5 \mathrm{TP}$ & $13.6 \mathrm{a}$ & 24 & $9.9 \mathrm{a}$ & 15 & $8.7 \mathrm{a}$ & 10 & $10.0 \mathrm{a}$ & 12 & $3.7 \mathrm{a}$ & 27 & $8.7 \mathrm{a}$ & 7 \\
\hline $01-0.1$ & 5 NT & $15.8 \mathrm{~b}$ & 15 & $11.7 \mathrm{~b}$ & 15 & $9.4 \mathrm{~b}$ & 13 & $11.0 \mathrm{~b}$ & 15 & $5.3 \mathrm{~b}$ & 24 & $10.1 \mathrm{~b}$ & 44 \\
\hline $15-0.3$ & TP & $14.4 \mathrm{a}$ & 9 & $2.1 \mathrm{a}$ & 13 & 11.2 & 20 & 9.5 & 13 & $5.2 \mathrm{a}$ & 25 & $10.3 \mathrm{a}$ & 9 \\
\hline $15-0.3$ & NT & $16.8 \mathrm{~b}$ & 17 & $4 \mathrm{~b}$ & 10 & 11.8 & 18 & 13.7 & 75 & $7.6 \mathrm{~b}$ & 17 & $4 \mathrm{~b}$ & 24 \\
\hline 5 & TP & $14.7 \mathrm{a}$ & 9 & 1 & 23 & .1 & 16 & 1 & 20 & $6.8 \mathrm{a}$ & 21 & 8 & 9 \\
\hline 5 & NT & $18.8 \mathrm{~b}$ & 23 & 1 & 18 & 1 & 2 & 1 & 22 & $8.1 \mathrm{~b}$ & 29 & 1 & 30 \\
\hline 6 & TP & 13.7 & 26 & 7 & 27 & $7 \mathrm{a}$ & 29 & 11.7 & 3 & 7.4 & 32 & 12.8 & 21 \\
\hline $45-0.6$ & NT & 15.7 & 29 & 12.2 & 34 & $10.5 \mathrm{~b}$ & 24 & 9.6 & 31 & 6.8 & 36 & 11.5 & 41 \\
\hline $6-0.9$ & TP & 12.6 & 52 & 10.4 & 50 & $10.7 \mathrm{a}$ & 47 & $10.1 \mathrm{a}$ & 38 & $6.8 \mathrm{a}$ & 45 & $11.1 \mathrm{a}$ & 44 \\
\hline 6-0.9 & NT & 15.8 & 41 & 8 & 34 & $7.2 \mathrm{~b}$ & 27 & $7 \mathrm{~b}$ & 36 & $4.4 \mathrm{~b}$ & 40 & $.8 \mathrm{~b}$ & 44 \\
\hline $9-1.2$ & TP & 9.6 & 3 & $9.4 \mathrm{a}$ & 48 & $8.7 \mathrm{a}$ & 42 & $8.3 \mathrm{a}$ & 35 & $5.4 \mathrm{a}$ & 55 & 6.9 & 56 \\
\hline $9-1.2$ & NT & 10.0 & 43 & $7.1 \mathrm{~b}$ & 18 & $5.8 \mathrm{~b}$ & 16 & $5.9 \mathrm{~b}$ & 15 & $3.6 \mathrm{~b}$ & 27 & 5.7 & 55 \\
\hline $1.2-1.5$ & TP & 9.2 & 30 & 8.6 & 24 & 7.8 & 16 & 7.8 & 24 & 4.9 & 40 & 5.2 & 37 \\
\hline 1.2 & NT & 11.5 & 50 & 7.5 & 21 & 7.5 & 50 & 6.8 & 17 & 4.8 & 35 & 6.4 & 41 \\
\hline \multicolumn{14}{|c|}{ * TP - Tilled plot; NT - No-till plot. } \\
\hline \multirow{2}{*}{\multicolumn{14}{|c|}{$\begin{array}{l}\dagger \text { Means }(\mathrm{n}=20) \text { for each date and depth, if followed by different letters, indicate } \\
\text { statistically significant differences in moisture content between the plots, by the two } \\
\text { sample t-test }(\alpha=0.05) \text {. } \\
\ddagger \quad \text { Coefficient of variation }(\%) \text {. }\end{array}$}} \\
\hline & & & & & & & & & & & & & \\
\hline \multicolumn{14}{|c|}{$\begin{array}{l}\S \text { There were no surface }(0-0.01 \mathrm{~m}) \text { samples taken on day } 272 \text {; the first core was taken } \\
\text { at depth } 0-0.15 \mathrm{~m} \text {. }\end{array}$} \\
\hline
\end{tabular}

Soil $\mathrm{pH}$ on all dates and depths were higher in the TP plot as compared to the NT plot. While the lower $\mathrm{pH}$ in the top 0.15 or $0.3 \mathrm{~m}$ of the no-till plot could possibly be attributed to tillage effects, the same cannot be said about the subsurface $\mathrm{pH}$ differences between the plots. Most of the differences between the plots were statistically significant at the 95\% significance level (table 4). The differences in mean gravimetric moisture content and $\mathrm{pH}$ in the deeper layers indicate differences between the adjacent plots due to a factor other than tillage. Soil moisture content and $\mathrm{pH}$ data from the two plots also show distinct depthwise variations. Soil moisture content increased to the 0.3 to $0.45 \mathrm{~m}$ layer or 0.45 to $0.6 \mathrm{~m}$ layer in the TP plot and then decreased, while in the NT plot the layer of maximum moisture content was 0.3 to $0.45 \mathrm{~m}$ on all but one day $(0.15$ to $0.3 \mathrm{~m}$ on day 167). Soil $\mathrm{pH}$ increased to the 0.15 to $0.3 \mathrm{~m}$ layer in the NT plot and then decreased (excluding data from 0 to $0.01 \mathrm{~m}$ ), while in the TP plot the layer of maximum $\mathrm{pH}$ 
was either 0.3 to $0.45 \mathrm{~m}$ or 0.45 to $0.6 \mathrm{~m}$. These depth variations may be related to the eluviation of clay, seen in the particle size data.

Trend surface analysis of moisture content and $\mathrm{pH}$ data were performed on depth-averaged data (excluding data from the 0 to $0.01 \mathrm{~m}$ depth layer), calculated for the six sampling dates. The moisture content trends in the TP plot were all linear while all significant trends in the NT plot were parabolic. The trends accounted for $60 \%$ to $89 \%$ of the total variability in moisture content in the two plots (table 5). Trends for days 128 (linear) and 167 (parabolic) are shown in figure 4 . The trend in the TP plot on day 128 shows an increase in moisture content downslope towards the north edge of the plot (fig. 4a). Linear trends in the TP plot on other dates also show an increase in moisture content downslope. The parabolic trends in the NT plot were more complex (fig. 4b, 4d), and show an increase from the middle of the plot to the sides. Trend surfaces of moisture content are calculated for a smaller area with fewer observations $(\mathrm{n}=$ 20) and thus are more subject to edge effects and are less reliable than trend surfaces of $\mathrm{pH}(\mathrm{n}=40)$, and trend surfaces of sand and clay content $(n=35)$. The consistently higher moisture contents found in the TP plot in the 0.45 to $1.2 \mathrm{~m}$ depth layers is probably related to the trends in texture. The moisture content trends may also have been affected by the $2 \%$ slope to the north side of the plots.

The soil $\mathrm{pH}$ trends were mostly linear (first order), and accounted for $22 \%$ to $64 \%$ of the total variability of $\mathrm{pH}$ in the combined plot area (table 5). The linear trend of $\mathrm{pH}$ on day 128 is shown in figure 5, and is representative of trends found for other dates. Soil $\mathrm{pH}$ increases from the northeast to the southwest corner of the study area, which corresponds to the trend in clay content. The difference in $\mathrm{pH}$ from one end of the $42 \times 27 \mathrm{~m}$ area to the other end was sometimes close to one unit. The $\mathrm{pH}$ trend indicates that the distinct difference in $\mathrm{pH}$ between the plots (table 4) is not simply due to random variance in the sample data.

\section{Bromide - DePth to Center of Mass}

As a secondary objective, we examined if spatial trends in soil texture, moisture content, and $\mathrm{pH}$ had an impact on chemical movement in the soil profile. Depth to center of

Table 5. Results from trend surface analysis of depth-averaged gravimetric moisture content and $\mathrm{pH}$ data

\begin{tabular}{|c|c|c|c|c|c|c|c|c|c|c|}
\hline \multirow{2}{*}{$\begin{array}{l}\text { Soil } \\
\text { Property }\end{array}$} & \multirow{2}{*}{$\begin{array}{c}\text { Area } \\
\text { Covered } \\
\text { by Trend } \\
\text { Surfaces }\end{array}$} & \multirow{2}{*}{$\begin{array}{l}\text { Year- } \\
\text { day }\end{array}$} & \multirow{2}{*}{ Order } & \multicolumn{7}{|c|}{ Coefficients of Trend Equation } \\
\hline & & & & $r^{*} \beta_{0}$ & $\beta_{1}$ & $\beta_{2}$ & $\beta_{3}$ & $\beta_{4}$ & $\beta 5$ & $\mathrm{R}^{2} \dagger$ \\
\hline \multirow{12}{*}{$\begin{array}{l}\text { Moisture- } \\
\text { content (\%) }\end{array}$} & $\mathrm{TP}(18 \times 27 \mathrm{~m})$ & $90-118$ & 81 & 8.554 & -0.049 & 0.258 & & & & 0.838 \\
\hline & NT $(18 \times 27 m)$ & $90-118$ & $8--$ & & & & & & & \\
\hline & TP & $90-128$ & 81 & 8.050 & -0.106 & 0.219 & & & & 0.669 \\
\hline & NT & $90-128$ & $824 \quad 4$ & 45.466 & -2.028 & -0.144 & 0.029 & -0.006 & 0.013 & 0.672 \\
\hline & TP & $90-145$ & 51 & 7.063 & -0.108 & 0.255 & & & & 0.852 \\
\hline & NT & $90-145$ & $\begin{array}{lll}5 & 2 & -2 \\
-1\end{array}$ & -26.157 & 1.788 & 0.523 & -0.022 & -0.022 & 0.008 & 0.604 \\
\hline & TP & $90-167$ & $7 \quad 1$ & 6.556 & -0.060 & 0.225 & & & & 0.635 \\
\hline & NT & $90-167$ & 72 & 9.524 & -0.344 & 0.466 & 0.010 & -0.025 & 0.018 & 0.878 \\
\hline & TP & $90-209$ & 91 & 4.340 & -0.077 & 0.118 & & & & 0.656 \\
\hline & NT & $90-209$ & $\begin{array}{lll}9 & 2 & 1\end{array}$ & 17.554 & -0.656 & -0.225 & 0.010 & -0.0038 & 80.013 & 0.749 \\
\hline & $\mathrm{TP}$ & $90-272$ & 21 & 6.562 & -0.130 & 0.224 & & & & 0.893 \\
\hline & NT & $90-272$ & $2--$ & & & & & & & \\
\hline \multirow[t]{6}{*}{$\mathrm{pH}$} & Both plots & $90-118$ & $8 \quad 1$ & 6.563 & -0.026 & -0.021 & & & & 0.639 \\
\hline & $(42 \times 27 \mathrm{~m})$ & $90-128$ & 81 & 6.363 & -0.020 & -0.007 & & & & 0.377 \\
\hline & & $90-145$ & 51 & 6.592 & -0.020 & -0.020 & & & & 0.423 \\
\hline & & $90-167$ & $7 \quad 1$ & 6.287 & -0.013 & -0.011 & & & & 0.216 \\
\hline & & $90-209$ & $9 \quad 1$ & 6.510 & -0.015 & -0.010 & & & & 0.345 \\
\hline & & $90-272$ & 22 & 6.960 & 0.017 & -0.129 & -0.001 & -0.000 & 0.003 & 0.531 \\
\hline
\end{tabular}

mass of the non-reactive tracer, bromide, in the 20 sampling locations in each plot (table 6) was taken as an indicator of chemical movement in the soil profile. Trend surface analysis was performed on the bromide data from the two plots for six sampling dates. None of the trends were found to be significant indicating that spatial trends in sand and clay content, moisture content, and $\mathrm{pH}$, did not have an observable impact on chemical movement. To illustrate the lack of a consistent pattern, or trend, in the data, contours of bromide depth to center of mass for two dates are shown in figure 6. This result is not totally unexpected as other forms of variability, such as extrinsic variability due to chemical application and rainfall, will also influence the variability of chemical movement in soil. Apart from a correlation of 0.3 between moisture content and bromide concentrations in the NT plot on all depths of day 118 , correlation analysis on the raw data did not show any consistent correlation between chemical concentration in soil and moisture content or $\mathrm{pH}$.

\section{DiscuSsION}

This study shows that spatial variability of soil properties in the Coastal Plain can be very high and spatial trends can occur even at small scales (less than 1/6th of a hectare). It demonstrates the need for detailed site characterization before field studies to detect any marked spatial variability at a given site. The presence of spatial trends can be detected by taking samples on a systematic grid; at this site, a systematic grid of $16 \mathrm{~m}$ interval with 12 sampling points would have been adequate to detect the presence of textural trends. This information can help determine the suitability of the site for a particular field study, and can be used in developing a statistical design which accounts for the effects of the variability.

The result also has implications on simulating water and chemical transport in such soils, where the spatial variability of soil properties must be considered in the modeling process. In heterogeneous fields such as the one described in this article, modeling subsurface water and chemical transport by treating the field as uniform may lead to significant deviations from the actual response of the field.

\section{SUMMARY AND CONCLUSIONS}

Spatial variability of particle size, moisture content, and $\mathrm{pH}$ across an agricultural field of less than 1/6th ha $(48 \times$ $32 \mathrm{~m}$ ) in the Virginia Coastal Plain was examined using trend surface analysis. Sixty-eight percent of the total variability in sand content and $31 \%$ of the total variability in clay content was explained by regional parabolic trends. A semivariogram analysis showed no spatial correlation in the residuals of the particle size data trend surfaces.

Soil moisture and $\mathrm{pH}$ measurements also showed spatial trends at the study site. Statistically significant differences in subsurface moisture content and $\mathrm{pH}$ between the plots, found in an earlier study (Heatwole et al., 1992), can be attributed to these trends. The spatial trends in soil properties, however, did not translate directly into spatial trends in depth to center of bromide mass, indicating the influence of other factors in the variability of chemical distribution in the soil.

This study shows that spatial variability of soil properties in the Coastal Plain can be significant, even 


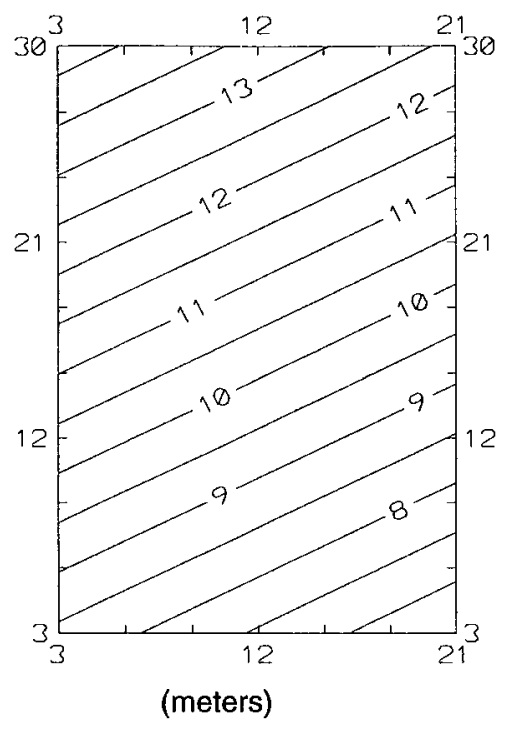

(a) Day 128, TP plot

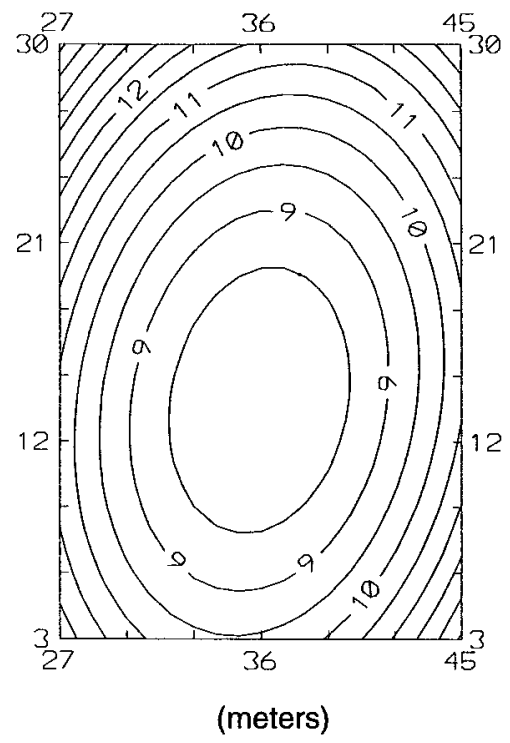

(b) Day 128, NT plot

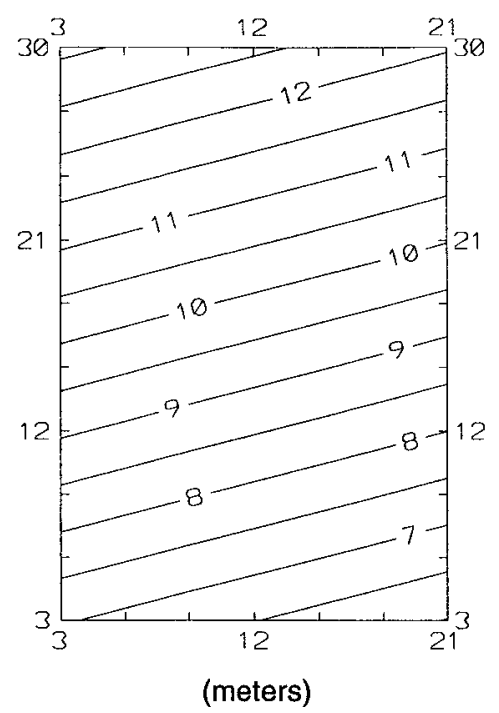

(c) Day 167, TP plot

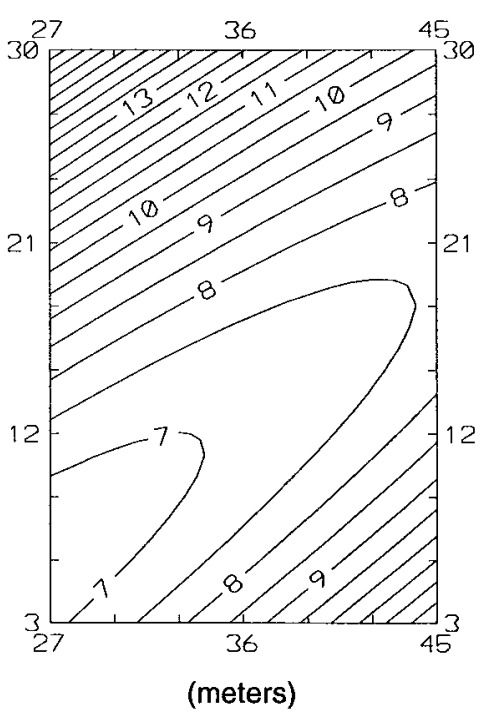

(d) Day 167, NT plot

Figure 4-Trend surfaces of depth-averaged soil moisture content $(\mathrm{mm} / \mathrm{mm})$ in the two plots: (a) day 128, TP plot; (b) day 128, NT plot; (c) day 167, TP plot; (d) day 167, NT plot.

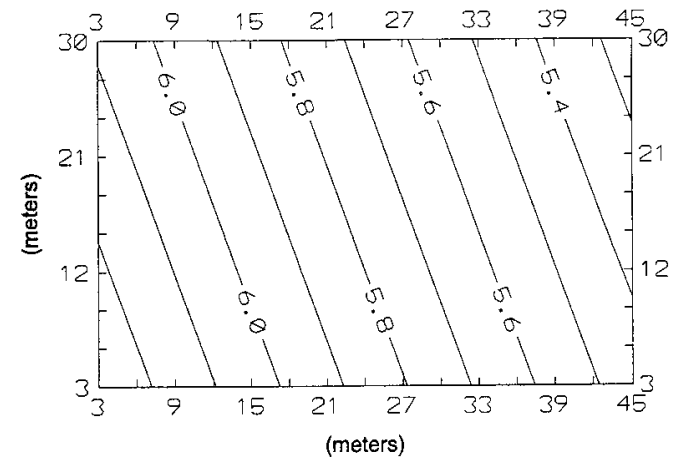

Figure 5-Trend surface of depth-averaged soil pH on day 128 using data from both plots.
Table 6. Summary statistics of depth to bromide center of mass in the top $90 \mathrm{~cm}$ of the soil profile in the two field plots by sampling date

\begin{tabular}{|c|c|c|c|c|c|c|c|c|c|c|c|c|}
\hline \multirow[b]{3}{*}{ Plot* } & \multicolumn{12}{|c|}{ Day of Year, 1990} \\
\hline & \multicolumn{2}{|c|}{118} & \multicolumn{2}{|c|}{128} & \multicolumn{2}{|c|}{145} & \multicolumn{2}{|c|}{167} & \multicolumn{2}{|c|}{209} & \multicolumn{2}{|l|}{272} \\
\hline & Mean & $\mathrm{CV} \dagger$ & Mean & $\mathrm{CV}$ & Mean & $\mathrm{CV}$ & Mean & $\mathrm{CV}$ & Mean & $\mathrm{CV}$ & Mean & $\mathrm{CV}$ \\
\hline TP & 18.3 & 50 & 21.8 & 43 & 29.6 & 41 & 45.4 & 17 & 42.8 & 16 & 43.0 & 16 \\
\hline NT & 18.8 & 53 & 26.8 & 29 & 30.5 & 29 & 45.5 & 12 & 41.2 & 21 & 39.3 & 26 \\
\hline
\end{tabular}

across an area of less than 1/6th ha. This implies that specific effort is required in the initial site characterization for a field study to identify spatial variability and trends. Trend surface analysis can be an important tool in such 


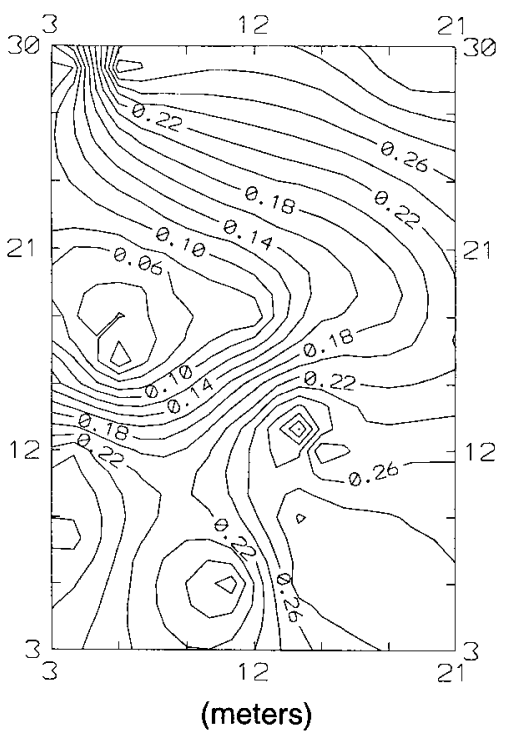

(a) Day 128, TP plot

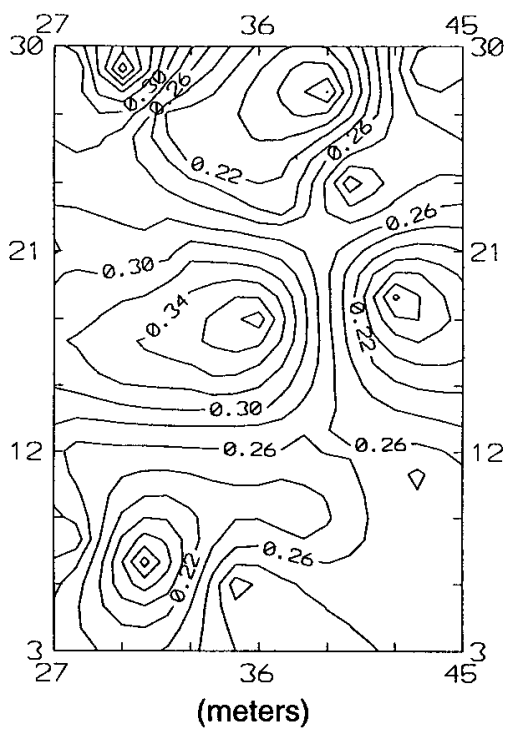

(b) Day 128, NT plot

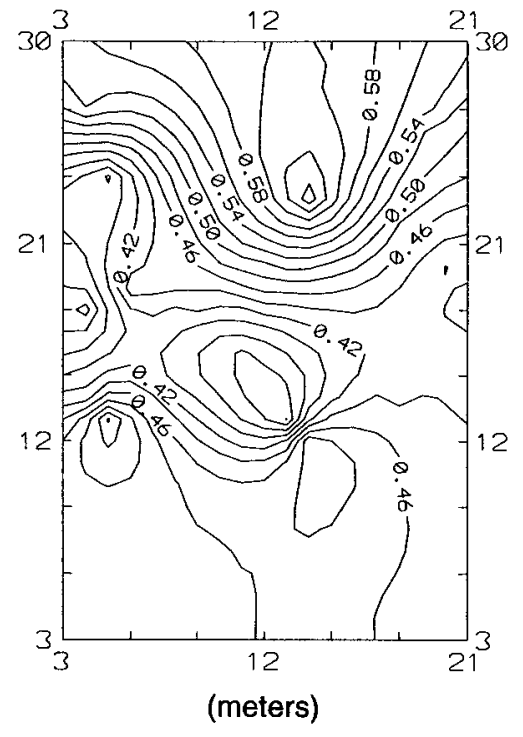

(c) Day 167, TP plot

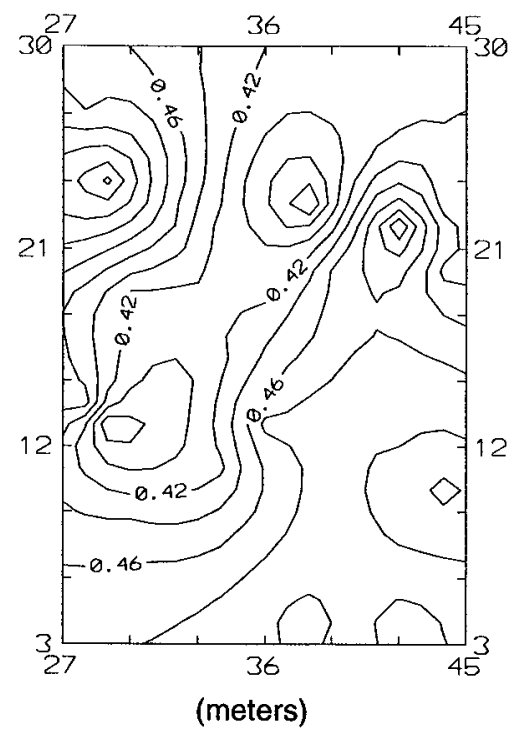

(d) Day 167, NT plot

Figure 6-Depth to center of bromide mass (m) in the two plots interpolated from 20 data points: (a) day 128, TP plot; (b) day 128, NT plot; (c) day 167, TP plot; (d) day 167, NT plot.

situations. A good statistical design must then be employed to try to remove the effects of the variability if the site is to be used to investigate treatment effects. When simulating water flow and chemical transport in such soils using computer models, the spatial variations in soil properties should also be taken into account to obtain realistic estimates of the output variables.

ACKNOWLedgments. Special thanks to graduate students who helped in soil sampling, Mr. W. T. Price for help in particle size analysis, and Dr. R. A. Cooke, Assistant Professor of Agricultural Engineering, University of Illinois, and Drs. W. J. Edmonds and N. Persaud, Associate Professors of Crop and Soil Environmental Sciences at
Virginia Tech, for suggestions and helpful discussions. We gratefully acknowledge the helpful comments of the anonymous reviewers. This article is based upon work supported, in part, by the Virginia Water Resources Research Center, the U.S. Department of the Interior, and the Cooperative State Research, Education, and Extension Service, U.S. Department of Agriculture, under Agreement No. 95-37102-2339.

\section{REFERENCES}

Beckett, P. H. T. and R. Webster. 1971. Soil variability: A review. Soils \& Fert. 34(1):1-15.

Bresler, E., G. Dagan, R. J. Wagenet and A. Laufer. 1984. Statistical analysis of salinity and texture effects on spatial 
variability of soil hydraulic conductivity. Soil Sci. Soc. Am. J. 48(1):16-25.

Cooke, R. A., S. Mostaghimi and C. D. Heatwole. 1994. A microcomputer-based routine for robust trend surface analysis. Applied Engineering in Agriculture 10(2):233-239.

Davis, J. C. 1986. 2nd Ed. Statistics and Data Analysis in Geology. New York, N.Y.: John Wiley \& Sons.

Gee, G. W. and J. W. Bauder. 1986. Particle size analysis. In Methods of Soil Analysis, Part 1 - Physical \& Mineralogical Methods, ed. A. Klute, 383-411. Madison, Wis.: Am. Soc. Agron.

Heatwole, C. D., S. Zacharias, S. Mostaghimi, T. A. Dillaha and R. W. Young. 1992. Fate and transport of pesticides in a Virginia Coastal Plain soil. Bull. 175. Blacksburg, Va.: Virginia Water Resources Research Center.

Heatwole, C. D., S. Zacharias, S. Mostaghimi and T. A. Dillaha. 1997. Movement of field-applied atrazine, metolachlor, and bromide in a sandy loam soil. Transactions of the ASAE 40(5):1267-1276.

Isaaks, E. H. and R. M. Srivastava. 1989. An Introduction to Applied Geostatistics. New York, N.Y.: Oxford University Press.

Matthews, R. K. 1974. Dynamic Stratigraphy. Englewood Cliffs, N.J.: Prentice-Hall, Inc.
Nielsen, D. R., J. Biggar and K. T. Erh. 1973. Spatial variability of field-measured soil-water properties. Hilgardia 42(7):215259.

Ott, R. L. 1993. 4th Ed. An Introduction to Statistical Methods and Data Analysis. Belmont, Calif.: Wadsworth Publ. Co.

Rao, P. S. C. and R. J. Wagenet. 1985. Spatial variability of pesticides in field soils: Methods for data analysis and consequences. Weed Sci. 33(Suppl.2):18-24.

Russo, D. and E. Bresler. 1981. Soil hydraulic properties as stochastic processes, I, An analysis of field spatial variability. Soil Sci. Soc. Am. J. 45(4):682-687.

Russo, D. and M. Bouton. 1992. Statistical analysis of spatial variability in unsaturated flow parameters. Water Resour. Res. 28(7):1911-1925.

Wierenga, P. J., R. G. Hills and D. B. Hudson. 1991. The Las Cruces trench site: Characterization, experimental results, and one-dimensional flow predictions. Water Resour. Res. 27(10):2695-2705.

Williams, R. D., L. R. Ahuja, J. W. Naney, J. D. Ross and B. B. Barnes. 1987. Spatial trends and variability of soil properties and crop yield in a small watershed. Transactions of the ASAE 30(6):1653-1660. 
